\title{
Encouraging Computational Skills: Evaluating BIM Course to Support Design Studio
}

\author{
Aswin Indraprastha \\ School of Architecture, Planning, and \\ Policy Development \\ Institut Teknologi Bandung \\ Indonesia \\ aswin@itb.ac.id
}

\begin{abstract}
Architectural education curricula are inevitably facing the challenge to lead and stay relevant to the expanding territory in architecture, engineering, and construction industries. The design studio, as a capstone of this education system, now meets the rise of computational tools in every aspect of the design process. The question arises on the method to incorporate the increasing development of computational tools into a systematic structure in the curricula that supports and enhance the design and its delivery. This study reports an analysis of the evaluation of five years of implementation of BIM-related courses in the undergraduate study planned to support the use of computational tools for the design studio at the School of Architecture, Planning and Policy Development, Institut Teknologi Bandung. This paper is concerned with the pedagogical approaches and content of teaching materials concerning limitations and constraints given by the curriculum structure. Using content analysis from course evaluation forms and interviews with the students, we analyze and suggest that the essential skills development necessary for the undergraduate level is modeling and documentation of design intent. The pragmatic approach that focuses on those two factors has benefit for design studio projects particularly on specific project typology with varied repetition components and less articulated form. However, our study also found that introducing BIM courses at $2^{\text {nd }}$ year of the undergraduate program was less useful since it required a proper understanding of additional and technical knowledge of building materials, construction, and others.
\end{abstract}

On the other hand, to tackle the great subjects of BIM, we employ a blended-learning system where we provided curated online tutorials into each of the BIM topics as complementary teaching materials. By this strategy, we optimize learning outcomes while minimizing the effort to pack a wide range of BIM subjects into teaching materials. Based on our findings, the value of computational BIM, therefore, lied on the comprehensive understanding of modeling design intent and integrated method for design delivery that we argue are essential for students entering the workforce. Furthermore, teaching computational skills through BIM to support design studio generates a computational milieu among the students where it encourages students to learn by their peers and various source materials that allowing them to expand their skills across platforms. We presented a detailed description and analysis of the course and outcomes, teaching agenda, student projects, feedbacks, findings, and discussion in the paper.

Keywords: BIM, design studio, computational skills

\section{BACKGROUND AND ISSUE}

Architectural education curricula inevitably facing the challenge to lead and stay relevant to the expanding territory in architecture, engineering, and construction industries. The design studio, as a capstone of this education system, now meets the rise of computational tools in every aspect of the design process, particularly BIM. There have been studies and researches by academia, mainly concerned with the studio-type learning environment that impacted by BIM. Ambrose in 2006 challenged design studio pedagogy to embrace an innovative design thinking into design studio using BIM application that delivered through an integrated process of design and construction with the support from various methods and tools such as simulation tool, fabrication tool. The point was the possibility of starting a design studio with a building rather than a conventional approach that ending with building design. BIM, as a methodology of design, might reposition curricular goals, concepts, and knowledge in the design studio [1]. In 2012, he suggested a studio model that seeks out a new method and pedagogical shift represented in BIM-based methodology by establishing new re-iterative relationships between design, data, and communication [2]. Ning Gu and de Vries (2012) proposed two approaches of implementing BIM into studio curricula by a focus on the collaboration aspect of BIM: 1) intra-disciplinary collaboration within architecture discipline and 2) interdisciplinary collaboration across disciplines[3]. Delatorre et al. (2015) reported another academic experience of teaching BIM in university, whereby one of the essential factors needed for understanding the BIM system was though interdisciplinary, collaborated, and integrated processes, supervised by lectures[4]. Another report came from Holzer (2019), suggesting the importance of blended learning methods of teaching BIM where learning content comprised of complementary in-class and curated online components[5].

Bringing into the context, BIM (Building Information Modeling) as a new platform and methodology in AEC (Architecture, Engineering, Construction) industry for design-construction-management workflows inevitably disrupts the design process from inception to the detailed design. In the context of BIM as information modeling, the principles and concepts behind 3D virtual building modeling and its representation are necessary to study, and therefore essential and object to be critically evaluated. Computational thinking, information database, and digital workflow underlying BIM software nowadays dated back in 1975 when Eastman [6] worked on the prototype of Building Description System (BDS) where single information in a 
database can be extracted into a visual representation and quantitative analysis. In the very beginning, BIM was intended to be a construction tool rather than purely a computer-aided design tool.

The recent study of BIM in the architecture curriculum investigated elective courses in which BIM associated with different computer programs for performance analysis [7]. To endorse environmental analysis at an early stage of the design process, the environmental analysis that presented in the study demonstrated that student could employ BIM as the tool, even without having previous experience with BIM. It leads to the potential of utilizing BIM for such analysis within the design studio curriculum.

Now with the ever-changing development and dynamic expansion of construction industries where key players such as architect/design consultant, engineering consultant, contractor, developer, vendor, builder, applicator, and other specialized professionals reinvent their workflow of designbuild, the needs for computational thinking and skills for architects are growing. BIM, as the technology, therefore, is relevant to be positioned as a platform and methodology for informational modeling of an architectural design process.

The computing topics in the School of Architecture, Planning, and Policy of Institut Teknologi Bandung (ITB) begin by introducing the basics and principles of computing [8] in the First Common Year Program. In our studio learning environment, computer as a design tool is introduced in the $4^{\text {th }}$ semester. Still, students are allowed to use a computer in the architectural design studio in their $3^{\text {rd }}$ year or starting in the $5^{\text {th }}$ semester.

To encourage and create a challenging learning environment, particularly on the BIM platform that serves as a supporting method for the design studio, we introduced two BIM-related courses in the $4^{\text {th }}$ and $6^{\text {th }}$ semester, respectively. Aside from BIM authoring skills, our primary goal is to develop computational design thinking and digital learning milieu in our design studio environment. We look forward to enriching the pedagogical aspect of a design studio with a new digital methodology and platform.

\section{THE BIM COURSES IN 2013-2018}

\section{A. Description of Compulsory BIM Subject}

In the 2013 undergraduate program curriculum, we introduced BIM on two BIM subjects that are included in the courses as follows:

1. Architectural Computation Studio (Compulsory) for the $4^{\text {th }}$ semester.

2. BIM Approach in Architectural Design (Elective) for the $6^{\text {th }}$ and $8^{\text {th }}$ semester.

As part of the Architectural Computation Studio, we introduced BIM as part of four technical skills that encapsulated in four areas: technical drawing, 3D modeling, architectural visualization, and fundamental BIM. For one semester, those four subjects had been taught in a workshoptype learning environment. In this course, the first part of each subject was general knowledge and principles underlying each of the subjects, followed by computer-lab subject tutorial and case-based learning in about 110 minutes per week.

The diagram below (Fig.1) shows the course agenda of Architectural Computation Studio:

\begin{tabular}{|l|l|l|}
\hline Week1 Week2 & Week3 & Week4 \\
\hline $\begin{array}{l}\text { Introduction to CAD, Drawing \& } \\
\text { Editing, Documentation }\end{array}$ & Total: 4 weeks \\
\hline $\begin{array}{l}\text { Intro to 3D modeling, modeling \& } \\
\text { editing, documentation }\end{array}$ & Total: 4 weeks \\
\hline $\begin{array}{l}\text { Interior \& exterior } \\
\text { rendering }\end{array}$ & Total: 3 weeks \\
\hline $\begin{array}{l}\text { Intro to BIM, family, parametric } \\
\text { component, basic data extraction }\end{array}$ & Total: 4 weeks \\
\hline
\end{tabular}

Fig. 1. Course agenda of the Architectural Computation Studio

In the total 8 learning hours over four weeks, the basic definition, principles of BIM had been introduced with emphasize on BIM as a method to create and develop a virtual $3 \mathrm{D}$ design and its role in the workflow of design and construction. In the following 4 weeks, the basics and essentials of component modeling and data extraction were taught in the tutorial session. Students were required to have a principal understanding of object modeling and object representation in BIM methodology. As part of course evaluation, the BIM assignment is an individual project where students required to model a simple structure (in this case: a two stories house) using standard or a family object modification. The output is a standard presentation board of drawings and tables of component schedules (Fig.2).
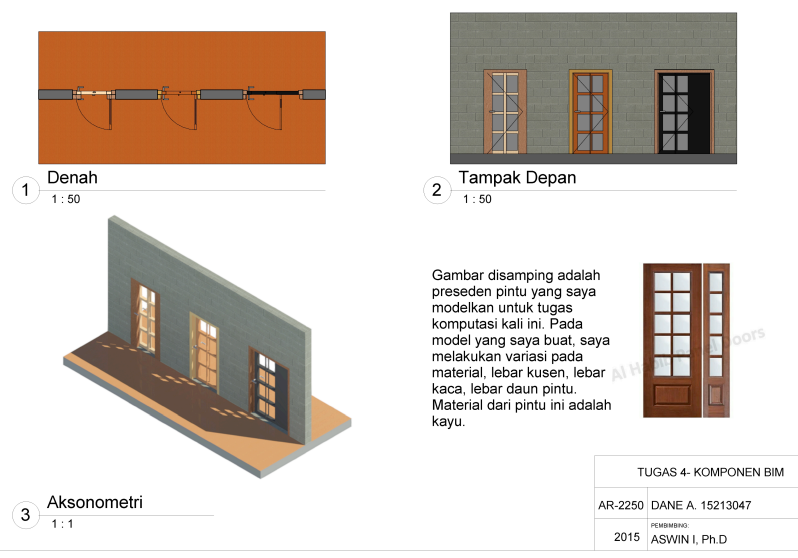

Fig. 2. Students work on a hosted family creation and modification showing basic principles of parametric modeling.

\section{B. Description of Elective BIM Course}

The elective BIM course that can be enrolled by the student in the $6^{\text {th }}$ or $8^{\text {th }}$ semester was prepared as an intermediate course of BIM. This 2 credits course comprises of two subjects, namely 1)) architectural BIM, and; 2) Collaborative BIM. The architectural BIM focused on the implementation of Autodesk Revit advanced features for the architectural design process while the collaborative BIM focuses on the implementation of collaborative aspects of 
Autodesk Revit with other disciplines: structure and plumbing. In this elective course, we had the privilege to collaborate with industrial partners for developing course materials and real project exercises on collaborative BIM. Fig.2 depicts the course agenda of BIM Course (AR-4222BIM Approach in Architectural Design):

\begin{tabular}{|c|c|c|c|c|}
\hline Week1 & Week2 & Week3 & Week4 & \\
\hline \multicolumn{2}{|c|}{$\begin{array}{l}\text { BIM in } \\
\text { construction } \\
\text { industry, setting- } \\
\text { up project }\end{array}$} & \multicolumn{3}{|r|}{ Total: 2 weeks } \\
\hline \multicolumn{4}{|c|}{$\begin{array}{l}\text { Component modeling: floor, roof, } \\
\text { openings, circulations, curtain walls, } \\
\text { mass modeling }\end{array}$} & Total: 4 weeks \\
\hline \multicolumn{2}{|c|}{$\begin{array}{l}\text { Family creation } \\
\text { and editing }\end{array}$} & \multicolumn{3}{|r|}{ Total: 4 weeks } \\
\hline \multicolumn{2}{|c|}{$\begin{array}{l}\text { Intro to } \\
\text { collaborative } \\
\text { BIM, setting up } \\
\text { central file }\end{array}$} & \multicolumn{3}{|r|}{ Total: 2 weeks } \\
\hline \multicolumn{2}{|c|}{$\begin{array}{l}\text { Workshop on } \\
\text { architectural } \\
\text { modeling and } \\
\text { editing in } \\
\text { consideration with } \\
\text { structure and } \\
\text { MEP modeling }\end{array}$} & \multicolumn{3}{|r|}{ Total: 2 weeks } \\
\hline \multicolumn{2}{|c|}{$\begin{array}{l}\text { Workshop on } \\
\text { clash detection } \\
\text { and rectification }\end{array}$} & \multicolumn{3}{|r|}{ Total: 2 weeks } \\
\hline & & & & Total: 16 weeks \\
\hline
\end{tabular}

Fig. 3. Structure of the BIM Approach in Architectural Design Course

The ratio of student/mentor in this course ranges from $1 / 20$ to $1 / 22$. We limited the quota for this course with a maximum of 40-45 students with 2 mentors. The assignment, in which we designed to be more elaborated on modeling, object and data representation, and collaboration report, consists of individual and team works. The individual works required students to remodeling their current design studio project with BIM, enriched with quantity reports. The team works required students to have reported on clash detection between significant architectural, structure, and plumbing components. In the team works, the principal building design model provided by our industrial partners. Each team required to modify architecture design models. In this second part of the course, our focus was on the principles of BIMenabled workflow in an architectural and engineering consultant where the architectural team is a part of the design and construction team. We introduced a collaborative scheme supported by our industrial partner (Fig.4):

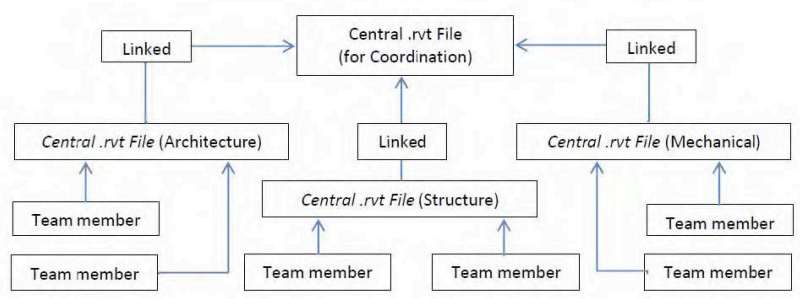

Fig. 4. Collaboration Scheme

This scheme provides the opportunity to explore methods of collaboration in Autodesk Revit, such as 1) Workset and 2) Linked Files. A group of students was assigned to do a remodeling project of a mixed-use complex building. The course grading system was given to each group based on each team appropriate alignment to the central file of the project that contains the basic levels and grinds, as well as the podium model of the apartment. [Fig.5].

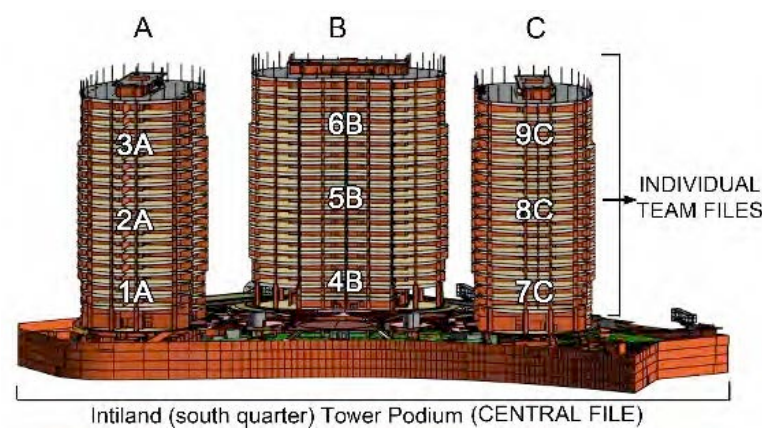

Fig. 5. Numbers show each group's responsibilities of remodeling about the central file of each tower. The industrial partner provided this project.

\section{Courses Evaluation And LeSson LEARned}

On the course experiences from 2013-2018, we collected data and information from student feedbacks on learning outcomes, method of delivery, and training materials. Furthermore, using data from the course evaluation form that authorized by ITB and interviews with the students, we conducted content analysis.

The evaluation and lesson learned of two BIM courses presented in the following section.

\section{A. Compulsory BIM Subject as Part of Architectural Computation Studio, $4^{\text {th }}$ Semester}

Architectural Computation Studio (AR2250, 3 credits), as mentioned in the previous section, put the BIM subject on week-9 to week-16. The BIM subject in this studio spans from 7 weeks to 5 weeks in a semester with course length about 2 hours/week within the 2013-2018 period. Over these periods, we evaluated course objectives, subjects, and class/lab exercises based on two inputs: 1) Students inputs through course evaluation questionnaires by the end of each course, and 2) Interview and discussion with alumni and our industrial partners. The evaluation system by questionnaires was provided by an online system provided by the university, where the result was reported back to the course coordinator in the form of a rating of evaluation indicators (Fig.6). 
Pertanyaan

1 Ketersediaan asisten/tutor menbantu saya dalam mengikuti matakuliah in. 2 Fasilitas praktikum/studio/asistensi/tutorial tersedia dengan memadai 3 Saya menikmati matakuliah ini

4 rrattikum/keria studio/asistensi/tutorial dilaksanakan sejalan dengan perkuliah

(a)

6 Saya memperoleh informa

7 Pelaksanaan perkuliahan diarahkan agar mahasiswa dapat mencapai atau menguasai luaran matakuliah ini

8 Saya mencapai atau menguasai luaran matakuliah ini.

9 Pelaksanaan perkuliahan terorganisir dengan balk

10 Dosen berkomunikasi dengan efektif.

11 Dosen peduli terhadap pencapaian atau pen

12 Dosen berlaku adil (fair) Kepada mahasiswa.

13 Beban kerja untuk matakuliah ini sesuai dengan SKS-nya.

15 Tersedia

15 Tersedia cukup fasilitas pendukung di luar kuliah yang memungkink

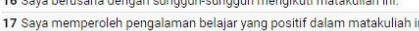

Fig. 6. Results of the Evaluation based on the questionnaires in the period of 2016-2017.

The resume and recapitulation of the course evaluation are depicted as follows (Table 1):

TABLE I. COURSE EVALUATION RESUlT

\begin{tabular}{lccccc}
\multicolumn{1}{c}{$\begin{array}{c}\text { Evaluation } \\
\text { Indicators }\end{array}$} & $2013-$ & $2014-$ & $2015-$ & $2016-$ & $2017-$ \\
& 2014 & 2015 & 2016 & 2017 & 2018 \\
\hline & & & & & \\
Course Goal & 0.9375 & 0.9375 & 0.885 & 0.7975 & 0.8175 \\
\hline & & & & & \\
Communication & 0.875 & 0.7575 & 0.795 & 0.9525 & 0.91 \\
\hline $\begin{array}{l}\text { Time- } \\
\text { management }\end{array}$ & 0.8775 & 0.915 & 0.65 & 0.7825 & 0.7725 \\
\hline $\begin{array}{l}\text { Course } \\
\text { Preparation }\end{array}$ & 0.935 & 0.9325 & 0.83 & 0.7825 & 0.7725 \\
\hline $\begin{array}{l}\text { Course load } \\
\text { and difficulty }\end{array}$ & 0.78 & 0.6125 & 0.605 & 0.8125 & 0.75 \\
\hline
\end{tabular}

\section{Architectural Computation Studio:} Course Performance

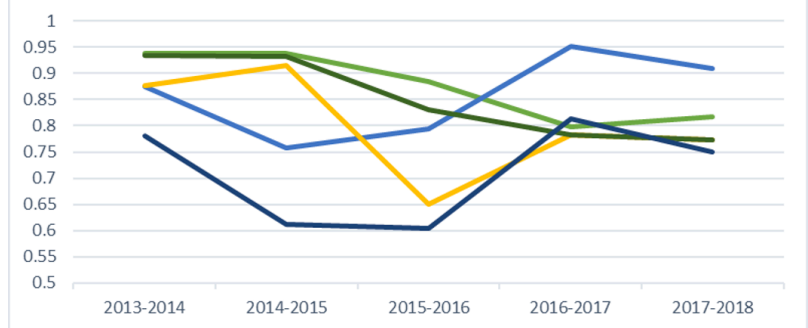

$$
\begin{aligned}
& \text { Course Goal } \\
& \text { Communication } \\
& \text { Course load and difficulty }
\end{aligned}
$$

Fig. 7. Result of the Performance of Architectural Computation Studio

The issue with the course's load became the primary concern given the fact that we tried to put multiple computation-related subjects and introduce multiple software with each has individual assignments, all in one semester (Fig.7). Students gave the lowest grading on this particular aspect even they feel confident with the course's goal and management by coordinator and mentors throughout the semester.

Furthermore, we conducted an evaluative analysis by organizing a group discussion with alumni and other stakeholders. The result of group discussion advised that the growing needs of BIM experts and professionals in the architectural, engineering, and construction industries lead to requirements of graduates who have basic understanding and skills of BIM at least for modeling/editing, has proper knowledge of information extraction/representation.

By this regular evaluation report, we revised our course plan and subjects that can be summarized as follows (Fig.89):

\begin{tabular}{|c|c|c|c|c|c|c|c|}
\hline \begin{tabular}{|l|}
$\begin{array}{l}\text { Course } \\
\text { Year }\end{array}$ \\
\end{tabular} & Weekl & Week2 & Week3 & Week4 & Week5 & Week6 & Week7 \\
\hline 2013-2014 & \begin{tabular}{|l} 
Introduction, \\
Workflow \& \\
UI
\end{tabular} & \multicolumn{3}{|c|}{ Family Concept \& Editor } & \multicolumn{2}{|c|}{ Component Modeling } & Quantification \\
\hline 2014-2015 & $\begin{array}{l}\text { Introduction, } \\
\text { Workflow \& } \\
\text { UI }\end{array}$ & \multicolumn{3}{|c|}{ Family Concept \& Editor } & \multicolumn{2}{|c|}{ Component Modeling } & Quantification \\
\hline 2015-2016 & $\begin{array}{l}\text { Introduction, } \\
\text { Workflow \& } \\
\text { UI }\end{array}$ & \begin{tabular}{|l} 
Family \\
Concept \& \\
Editor \\
\end{tabular} & \multicolumn{2}{|c|}{ Component Modeling } & $\begin{array}{l}\text { Project } \\
\text { Documentation }\end{array}$ & Quantification & \\
\hline 2016-2017 & $\begin{array}{l}\text { Introduction, } \\
\text { Workflow \& } \\
\text { UI }\end{array}$ & \multicolumn{2}{|c|}{$\begin{array}{l}\text { Basic Parametric } \\
\text { Component Modeling }\end{array}$} & \multicolumn{2}{|c|}{ Project Documentation } & & \\
\hline 2017-2018 & \begin{tabular}{|l|} 
Introduction, \\
basic \\
parametric \\
component \\
modeling
\end{tabular} & \multicolumn{2}{|c|}{$\begin{array}{l}\text { Parametric component } \\
\text { modeling }\end{array}$} & $\begin{array}{l}\text { View } \\
\text { Templates \& } \\
\text { Sheet } \\
\text { production }\end{array}$ & $\begin{array}{l}\begin{array}{l}\text { Rendering \& } \\
\text { visualisation }\end{array} \\
\text {. }\end{array}$ & & \\
\hline
\end{tabular}

Fig. 8. Course Plan Development

\begin{tabular}{|c|l|l|r|}
\hline No & Subjects & $\begin{array}{l}\text { Total } \\
\text { Weeks }\end{array}$ & $\mathbf{1 0 0 \%}$ \\
\hline 1 & $\begin{array}{l}\text { Introduction, } \\
\text { Workflow \& UI }\end{array}$ & 1 & 0.17 \\
\hline 2 & $\begin{array}{l}\text { Basic Parametric } \\
\text { Component } \\
\text { Modeling }\end{array}$ & 3 & 0.50 \\
\hline 3 & $\begin{array}{l}\text { Documentation \& } \\
\text { Quantification }\end{array}$ & 2 & 0.33 \\
\hline & Total & 6 & \\
\hline
\end{tabular}

Fig. 9. Course Subjects

As part of Architectural Computation Studio in the fourth semester, we inspected that the BIM subjects in this course had an insignificant effect and role in the context of computational skills they used in the following semesters, particularly for Architectural Design Studio due to the facts and factors such as:

1. The modeling approach in BIM software is less intuitive, more complex, and required a prior understanding of material and construction than other 3D modeling software (i.e., Trimble's SketchUp).

2. Second-year students had been introduced to the Structure, Construction and Material Studio, which has a minor impact on their understanding of material properties and construction during which form exploration being exercised using BIM software in the same year.

3. BIM software limits creative and flexibility of formmaking compared with other 3D modeling software, constrained students by the rigid system, structure, and 
parameters. Understandably, BIM software is not primarily for design exploration.

Our further observation of the Architectural Design Studio at $3^{\text {rd }}$ year on the span of 2014-2018 found other interesting facts as follows:

1. Adaptation and implementation of BIM in Architectural Design Studio, depending on the typology of the studio project. It is found that students are more confident and felt it was more productive using BIM software when the studio project or assignment is a hotel or apartment/housing typology. Not only there are more repetitive components, but the design explorations are more constrained compared with another typology (e.g., museum, gallery).

2. Adaptation and adoption of BIM skills into design studio workflow needs time to grow and period of being internalized among students and their learning environment. We found that students could learn better from their peers when needed. In 2013, the first year of BIM implementation in the curriculum through compulsory Architectural Computation Studio, it has insignificant effect on the Design Studio in the design studio that follows. Students were familiar with more intuitive 3D modeling software. However, in 2018, a $27.5 \%$ class of the Architectural Design Studio III ( $3{ }^{\text {rd }}$-year student) using BIM authoring software (Autodesk Revit or Graphisoft ArchiCAD) as the primary design tool. Those students were taught BIM subject in their $2^{\text {nd }}$ year of 2017 through Architectural Computation Studio. Moreover, about $36 \%$ of students in their $4^{\text {th }}$ year used BIM as the primary design tool since the design projects were an apartment typology with commercial function at the podium. Furthermore, depends on the project typology they chose for the final project, $10 \%$ of hotel typology, $12 \%$ of apartment typology, and $11 \%$ of office typology were being designed using BIM as opposed to using other digital design authoring tools.

3. BIM skills required by the student obviously in correlation with the design studio output. The student tends to be pragmatic and trying the best conceivable way to avoid much tedious drawing works when it comes to the tool, they use for developing and producing convincing results of their design ideas. If BIM software provides methods to automate the production of technical drawings, they learn and use BIM software.

\section{B. Elective BIM Course, $6^{\text {th }}$ Semester}

From the period of 2013 to 2018, there have been evaluation, revision, development, and improvement of the course's objectives, subjects, and student assignments based on the evaluation feedbacks from the students represented on the questionnaire result (Table II). The course subjects that initially developed in 2013 to be the intermediate level of the compulsory computation studio provided knowledge and skills for architectural modeling and collaborative data management. However, as depicted in Fig.8, since 2016, we reduced subjects of collaborative and management subjects and more on parametric architectural modeling and project management, including templates and documentation that we believe are more necessary for students at the bachelor level.

\begin{tabular}{lccccc}
\multicolumn{1}{c}{$\begin{array}{c}\text { Evaluation } \\
\text { Indicators }\end{array}$} & $\begin{array}{l}2013- \\
\text { Ind }\end{array}$ & $\begin{array}{l}2014- \\
2015\end{array}$ & $\begin{array}{l}2015- \\
2016\end{array}$ & $2016-$ & $2017-$ \\
& 2018 \\
\hline Course Goal & 0.8825 & 0.9225 & 0.9125 & 0.7375 & 0.87 \\
\hline Communication & 0.83 & 0.8425 & 0.8375 & 0.8975 & 0.9575 \\
\hline $\begin{array}{l}\text { Time- } \\
\text { management }\end{array}$ & 0.7675 & 0.8525 & 0.765 & 0.805 & 0.9025 \\
\hline $\begin{array}{l}\text { Course } \\
\text { Preparation }\end{array}$ & 0.88 & 0.92 & 0.905 & 0.805 & 0.8975 \\
\hline $\begin{array}{l}\text { Course load } \\
\text { and difficulty }\end{array}$ & 0.805 & 0.695 & 0.7825 & 0.6625 & 0.9025 \\
\hline $\begin{array}{l}\text { Comprehension } \\
\text { and }\end{array}$ & & & & & \\
Understanding & 0.84 & 0.7575 & 0.7075 & 0.7375 & 0.87 \\
\hline
\end{tabular}

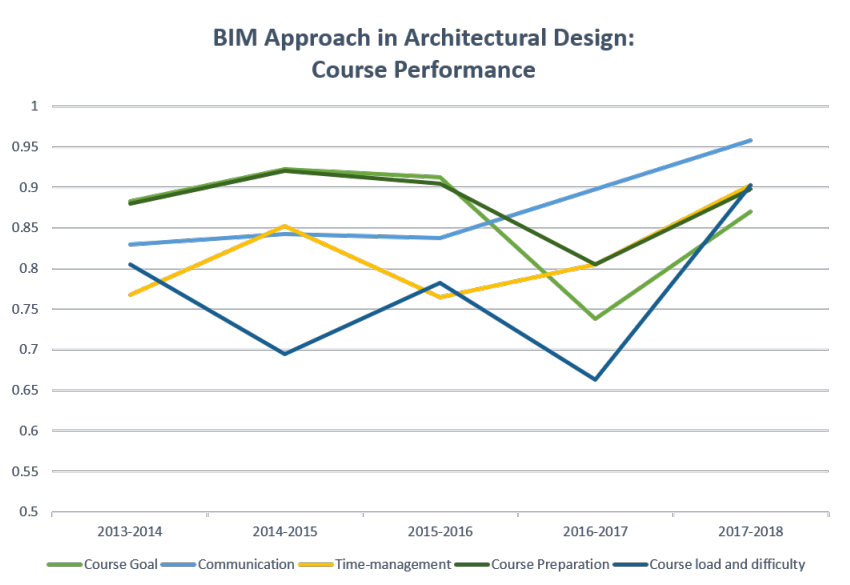

Fig. 10. Result of the Performance of BIM Approach in Architectural Design Course

The result data in Table II and Fig. 10 shows that despite has 2 credits with two individual assignments in one semester, the student felt they comprehend most of the course materials and did not complain about the working hours that excess standard 2 credits for an elective course.

Besides, the course evaluation of 2017-2018 indicated feedbacks from students suggesting what improvement they needed the most in the course:

1. The learning module should be prepared at least 2 days before class begins.

2. All required plug-ins or add-ins and extension file should be installed before class begin

Fig. 11 below indicated the process of iteration of course's subjects in 2013-2018. Note that parametric modeling subjects are the focus of the course, followed by project setup, templates, and documentation (Fig.11-12). 
to submit an analysis report of the design performance (e.g., green building indicators) for construction permit document.

\section{USING BLENDED LEARNING PLATFORM}

As BIM topics became popular among architecture students, the needs for BIM professionals are growing in AEC industries. Meanwhile, there is a tendency to increase the type of software in the BIM ecosystem, and each has a method to solve a particular problem, which leads to abundant sources of learning material on the internet. By narrowing it down to the architectural design process, there are still growing numbers of methodology involving standalone software or multiple software.

To tackle the great subjects of BIM and make sure that the student learned from legitimate learning sources, we employ a blended-learning system where curated online tutorials are provided into each of the BIM topics as complementary teaching materials. By this strategy, we are optimizing learning outcomes while minimizing the effort to pack a wide-range of BIM subjects into teaching materials.

Diagram depicted in Fig.13 shows our blended learning platform using Schoology (schoology.com) of 2017-2018 elective BIM course learning material. The course divided into 6 modules, where each module consists of weekly topics and curated online tutorials. In our experience, two hours of lecture and workshop style of teaching method was inadequate to achieve the course target of each week. Therefore, online tutorials specially curated and relevant with each week teaching materials are essential and could expand comprehension of the specific topic.

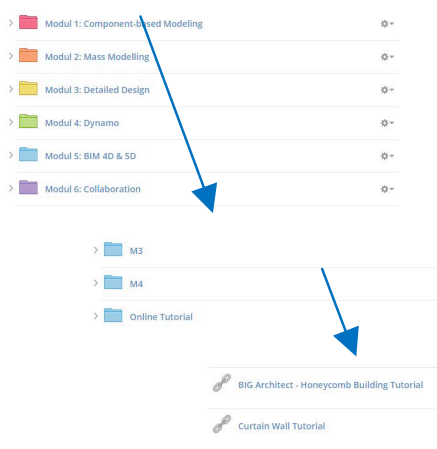

Fig. 13. Curated online tutorials

Also, for storing teaching materials, the blended learning platform used for assignment submission, review, and grading platform as in the figure below (Fig.14):

P: Component Modeling

PM: Parametric Modeling

PC: Project Stup, Documentation, Visualisation

CL: Collaboration Method

Fig. 12. Percentage of Course Subjects 2013-2018

As the course intended to be supporting courses for studios, most of the $3^{\text {rd }}$ or $4^{\text {th }}$-year students chose this course primarily to learn intermediate BIM skills for their studio projects and further equipped them to enter the workforce in AEC industries, especially in work as architects of design professionals. Furthermore, some students think that BIMbased performance analysis should be included in the course. They believed in the professional practice, the building regulation authority required architects or design consultants

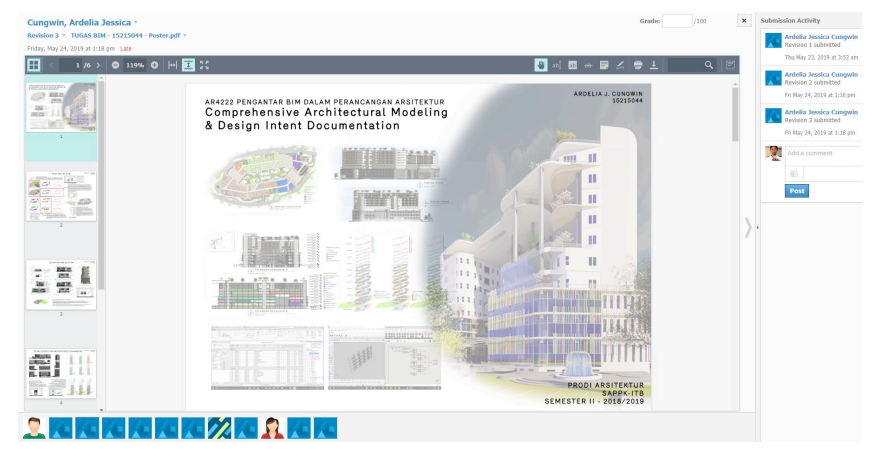

Fig. 14. Assignment submission platform 
Our review of using blended learning as a complementary teaching platform was positive. Students found this platform useful, easy to use, and helpful for achieving learning outcomes.

\section{The IMPACT OF BIM IN DESIGN STUdio}

As indicated on the title of this paper, after five years of implementation and evaluation of course's learning outcome, method of delivery, and teaching materials, we currently observe a growing number of students that take the opportunity to explore the potentiality of BIM in their design studio. In particular, the elective BIM course, we integrated course assignment with the design studio project where the focus of BIM assignments is to explore student's ability to develop their comprehensive architectural modeling and design intent documentation. By this strategy, students were forced to explore BIM as a design tool, finding the best workaround to incorporate other software for design exploration, and generating design intent documentation using BIM features. Focus on architectural BIM subjects also help our students focus on features of BIM they need to accomplish the design studio project. Subject such as collaborative BIM, however crucial in the real BIM implementation, we took as 1-2 lecture sessions, introducing the complete system of BIM collaborative works. Fig.1516 depicted a sample result of student design studio works in the $3^{\text {rd }}$ and $4^{\text {th }}$ year using BIM.

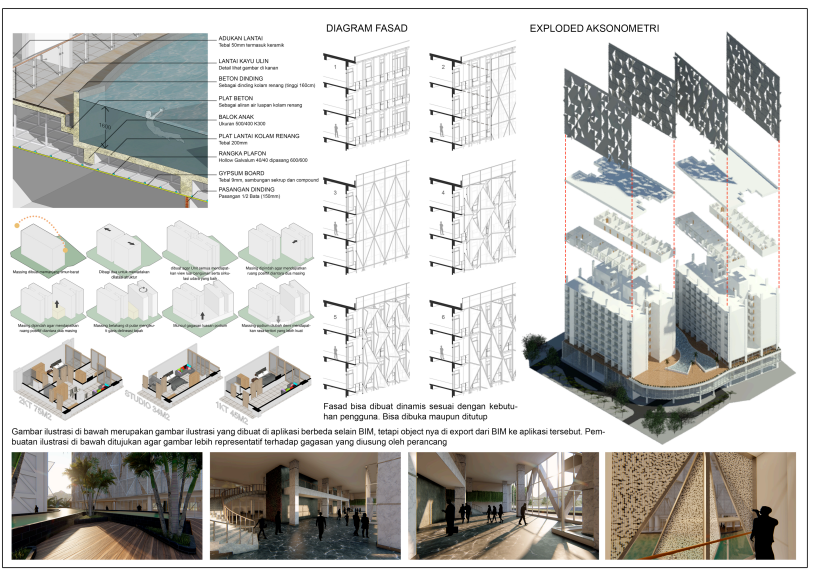

Fig. 15. A $3^{\text {rd }}$-year studio works by Kahfi Azis

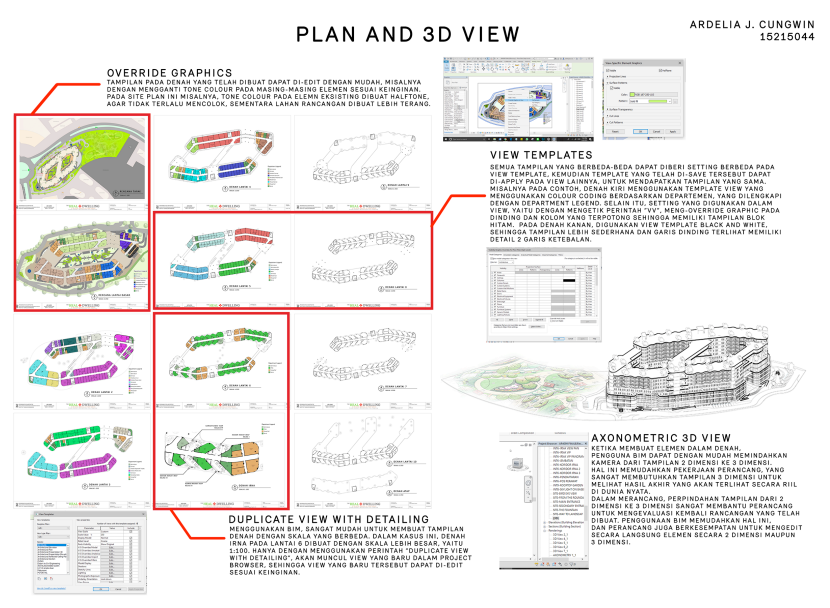

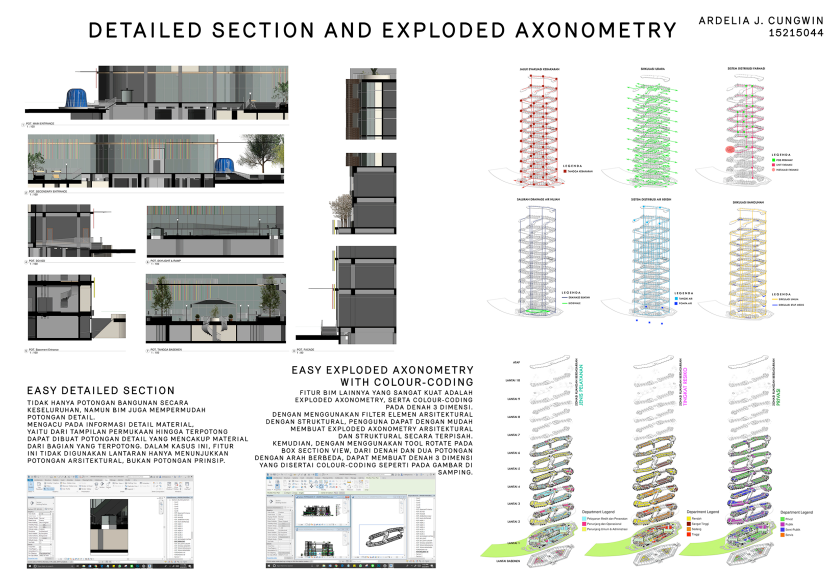

Fig. 16. A $4^{\text {th }}$ year Student Works by Ardelia Cungwin

Based on the 2017-2018 course evaluation, concerning our school's studio culture and curricula, we came into the conclusion in which BIM courses could enhance design studio. The recommendation has resulted in four aspects:

1. Learning outcomes; focus on the architectural modeling, analysis, and project documentation that needed the most for a design studio project.

2. Course agenda; the combination of teaching principles and concepts with hands-on tutorial style is appropriate based on the case of a design studio. The 14-16 weeks of the course agenda should be integrated with the design studio schedule.

3. Method of delivery; blended learning with curated online teaching materials, in addition to the handout of weekly learning subject, is favorable by the students to keep pace with the course agenda.

4. Teaching and training materials; preparation of teaching and learning materials, including the type of exercise relevant to the weekly subject.

The computational thinking and skills in architecture design curricula should be regarded as a new method of a design process that required an incremental shifting of architectural design pedagogy and fundamentally change how to run a design studio. As with other types of disruption, BIM offers the potential to enhance design modeling, analysis, and production that should be taken carefully and critically.

The value of computational BIM, therefore, lied on the comprehensive understanding of modeling design intent and integrated method for design delivery that we argue are essential for students entering the workforce.

Furthermore, teaching computational skills through BIM to support design studio generates a computational milieu among the students where it encourages students to learn by their peers and various source materials that allowing them to learn by themselves. 
[5] D. Holzer, Teaching Computational Design and BIM in the Age of (Semi)flipped Classrooms. Proceedings of CAADRIA 2019.pp. 715 724, 2019.

[1] M. A. Ambrose, BIM and Comprehensive Design Studio Education. Proceedings of CAADRIA 2009, pp.757-760, 2009.

[2] M. A. Ambrose, Agent Provocateur - BIM in the Academic Design Studio. International Journal of Architectural Computing (IJAC). Issue 01, Vol.10. pp. 53-66, 2012.

[3] Ning Gu, and Bauke de Vries, Two Approaches to Implementing BIM in Architectural Curricula. Proceedings of eCAADe 30. Pp $39-48$, 2012.

[4] V. Delatorre, et al, BIM: Application Reports in the Teaching of Architecture. Proceedings of SIGRADI 2015 pp.30-37, 2015.

[6] C. Eastman, The Use of Computers Instead of Drawings in Building Design. AIA Journal. 63, 1975.

[7] W. Abdelhameed, BIM in architecture curriculum: a case study, Architectural Science Review, 61:6, pp. 480-491, DOI: 10.1080/00038628.2018.1483888, 2018.

[8] Institut Teknologi Bandung (2013). Undergraduate Program of Architecture Curricula. [Online]. Available at. https://sappk.itb.ac.id/struktur-kurikulum-2013-prodi-arsitektur-s1/ 